\title{
The Effects of Community Based Watershed Management on Livelihood Resources for Climate Change Adaptation the Case in Gemechis District, Oromiya
}

\author{
Dejene Teressa* and Etefa Guteta \\ Department of Natural Resources and Environmental Science, Oda Bultum University, Ethiopia
}

Submission: October 14, 2018; Published: October 24, 2018

*Corresponding author: Dejene Teressa, Department of Natural Resources and Environmental Science, Oda Bultum University, PO. Box, 226 Chiro, Ethiopia

\begin{abstract}
This study was carried out in Gemechis district, Oromiya regional state to evaluate effects of community-based watershed management on livelihood resources for climate change adaptation. A total of 240 sample households were selected randomly from all farmers engaged in farming activities. Data were collected through field observations, household questionnaires survey, focused group discussion and key informants interview. The qualitative data obtained were analyzed qualitatively using appropriate words. Quantitative data were analyzed by descriptive statistics such as frequency and percentages. Results of this survey indicated that more than half, i.e. $94.2 \%, 91.3 \%$ and $68.3 \%$ of the respondents were gained good attentiveness about soil bunds, stone bunds and contour plowing respectively. Likewise, crop rotation, intercropping, organic manure/compost and tree planting have acquired good attention by $85 \%, 90.8 \%, 100 \%$ and $100 \%$ of the respondents, correspondingly.

However, only $10 \%, 6 \%, 6.7 \%, 11.7,5 \%$ and $22.5 \%$ of the respondents revealed good awareness about trenches, eye brow basins, micro basins, check dams, and water ways construction, respectively. Considering watershed management practices as an alternative measure, $84.2 \%, 94.2 \%, 35 \%$ and $68.3 \%$ of the respondents were implement soil bund, stone bund, water ways and contour plowing on their farm land consecutively. Additionally, 27.03\%, 90.8, 19.58, 1.7\%, of them were implemented crop rotation, intercropping, mulching and fallowing on their farm land consecutively. Even though the study area is categorized under moisture stressed, the attention given for implementation of in-situ moisture conservation structures were very low. Only $16.6 \%, 15 \%, 6.7 \%$ and $11.7 \%$ of them were implemented trenches, eye brow basins, micro basins and semicircular bunds on their farm lands sequentially. This implemented watershed management interventions through community mobilization results multiple positive effects on people's livelihoods resources. In line with this, $96.7 \%$ of the respondents were stated that soil erosion was reduced moderately (25-50\%), $98 \%, 93 \%$ and $78.8 \%$ of the respondents were also stated change in soil moisture retention, ground water table and capacity as a moderate (25-50\%), respectively. And $96.7 \%$ and $75 \%$ of the respondents were observed moderate improvement in soil fertility and crop yield respectively. Therefore, based this survey result it can be possible to conclude that watershed management intervention can bring significant change on the livelihood resources for climate change adaptation.
\end{abstract}

Keywords: Community; Awareness; Implementation; Impact and Livelihood

\section{Introduction}

Ethiopia is one of the most vulnerable country to adverse effects of climate change due to its geographical location, topography and heavily dependent on rain-fed agriculture, under development of water resources, high population growth rate, low economic development level, inadequate road infrastructure in drought prone areas, weak institutions in combination with low adaptive capacity [1]. Increasing weather variability and climate change are contributing to land and natural resource degradation by exposing soils to extreme conditions and straining the capacity of existing land management practices to maintain resource quality [2]. Finally, its results degradation of vegetation cover and loss of biodiversity, soil erosion, depletion of organic matter, reduced rainwater infiltration and water holding capacity of the soil and loss of productivity and effects on wider ecological functions. It is unquestionably inducing changes to natural and social systems. The effects of these changes are already serious and are growing further currently. These ongoing changes highly threaten human development for the world of poor and spreading to the entire world becoming long term dangers for all human beings [3].

The increased vulnerability to drought and food insecurity is directly linked to the degraded conditions of the watershed and their effects on limiting its capacity to support local livelihoods. The opposite occurs with protected and well managed watersheds, which generate multiple positive effects on people's livelihoods, the environment and for the overall economy of the area [4]. Therefore, application of community-based watershed management is the most modern and recently developed method 
of land rehabilitation and climate change adaptation [5]. Its emphasis on integrated use and management of land, vegetation and water resources in a geographically discrete catchment or drainage area through people centered approaches with all stakeholders, for the benefit of residents and wider society, through enhancing productivity and livelihoods and maintaining the range of ecosystem services, in particular the hydrological services that the watershed provides, and reducing or avoiding negative downstream or groundwater impacts.

A series of studies has shown that successful community based resource management can potentially enhance the resilience of communities to the impacts of climate change, as well as maintaining ecosystem services and ecosystem resilience as cited in [6,7] also recommended this approach to adapt the impacts of climate change in Ethiopia to strengthen the communities abilities to adapt and cope with the growing threats of climate change and improving their livelihoods. Community based integrated watershed management is the current approach which requires involvement and contribution of local people. In view of this, the government Ethiopia announces 30 days public campaign work for implementation of watershed management practices in the last four years all over the country. Therefore, these 30 days watershed management labor contribution by farmers has been practiced in most wereda's including Gemechis districts.
However, few complete studies examined the extent to which community-based watershed management interventions have resulted in the desired effects. In other way, effect of such watershed management interventions, on biophysical and socio-economic components for climate change adaptation are rarely evaluated. Therefore, this study was initiated to assess the awareness, implementation and also effects watershed management interventions on livelihood resources for climate change adaptation in Gemechis district. Furthermore, this study was intended to supplement the previous studies and to give recent information for the people in the area, the GOs, the NGOs, and the agricultural experts who are engaged in SWC.

\section{Materials and Methods}

\section{Description of the Study Area}

The study was conducted in Gemechis district of West hararghe zone, Oromiya regional state. Gemechis district is one of the 14 districts in West hararghe zone which is located at $343 \mathrm{~km}$ East of Addis ababa and about $17 \mathrm{~km}$ south of Chiro, capital town of the zone. It shares borders with Chiro district in the West and North, Oda Bultun district in the South and Mesela district in the east [8]. The district covers an area of 77,785 ha and it has 35 rural and one urban peasant association. The total population of the district is 184,032 of which 93659 are males and 90373 are females.

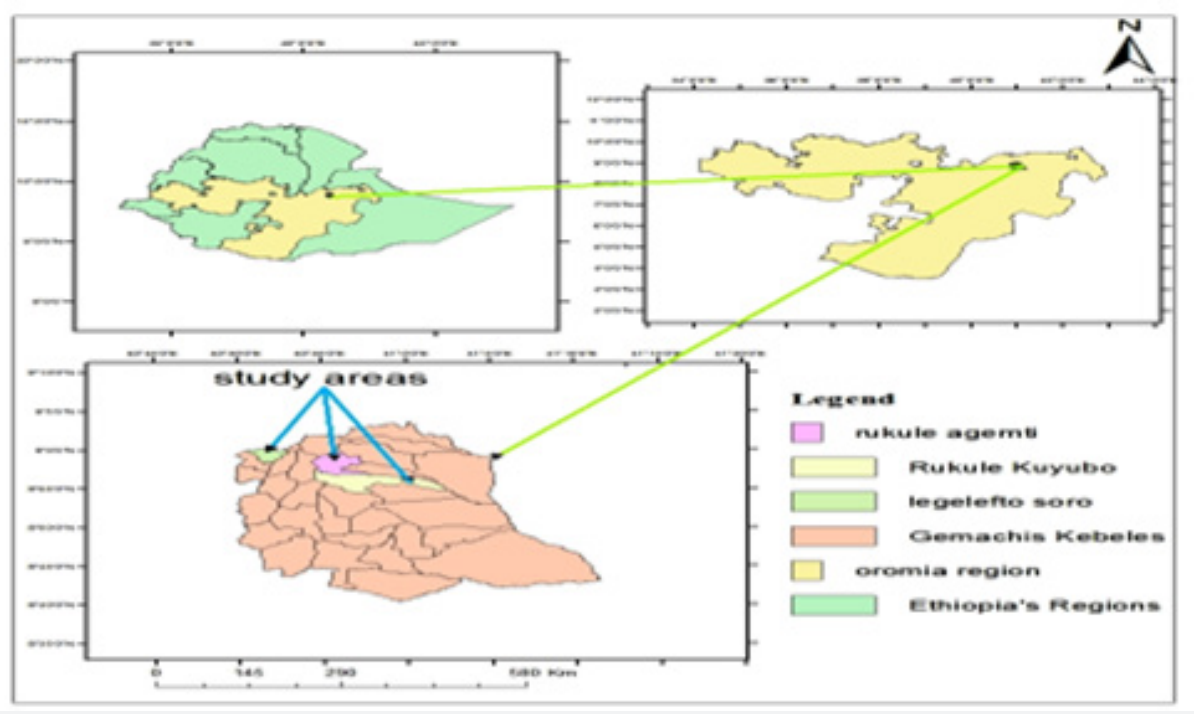

Figure 1: Map of study area.

The numbers of agricultural households in the district is estimated to 38,500 with 32,308 males headed and 6,192 females headed. The average family size is estimated to be 6 and 4 per house hold in rural and urban areas respectively. The district is found within 1300 to $2400 \mathrm{~m}$ above mean sea level. It receives annual rain fall of $850 \mathrm{~mm}$. It has bimodal distribution in nature with small rains starting from march/April to May and the main rainy season extending from June to September /October. The average temperature is $20^{\circ} \mathrm{c}$. Regarding the land use patter of the district, 32994.5ha were cultivated, 6185 ha were grazing, 1385 ha were covered by forest, bushes and shrubs, 6603.62 ha were arable and 17949. 34 are being used for other purposes such as encampment, infrastructure facilities. The black brown and red soils are the three dominant soil types constitute 55, 25 and $205 \%$ respectively (Figure 1).

\section{Methods}

Site selection, Sampling Techniques and Sample Size: This study involved different and multistage sampling techniques. 
The study zone and Woreda were selected purposively. From the selected Woreda four-wheel accessible kebeles were categorized into agro-ecological groups. After these considerations, three kebeles (Rukule kuyyubbo, Rukule Agamtii and Lega lafto Soro) were randomly selected from all agro-ecological category and all micro-watersheds within the kebeles, where watershed management has been implemented by campaign work were considered for study.

The total household heads in the study area were identified and stratified into two strata's: farmers who engaged in farming activates and others. Then the representative sample was selected randomly from the former strata (farmers engaged in farming activates). Factors like the homogeneity of population, cost of the survey, shortage of time, large number of factors to be analyzed and the precision level required was taken in to consideration while deciding sample size. The sample size was determined by using the following formula at $95 \%$ confidence interval, 0.05 degree of variability and $95 \%$ level of precision as cited in [9].

Where $\mathrm{n}$ is the sample size, $\mathrm{N}$ is the total household heads size, and e is the level of precision.

Fifteen Focused group discussions (each comprising 5-15 participants) were conducted based on checklists and semistructured questionnaires, and in-depth interview were used for collection of the data. During this session, respondents were Result and Discussion expressed their opinions, views, feelings and perspectives about the community-based watershed management implementation process and outcomes. The main objective of this method is to triangulate the survey method and investigate additional facts that were not addressed by the survey method. Moreover, key informants' interviews were conducted with 4 elders, 4 local administrators and 4 experts.

The main data collection tools used were observation checklist, key informant guide, focus group discussion guide, Semi Structured Interview schedule (open ended, close ended and scale item questions are addressed) and a field practices performance evaluation check list. Household Questionnaire Survey was used to collect the primary data from sample households. This survey was focused on individual household's participation in watershed management and also to get information on farmer's field practices of land resource management.

Data Analysis: Both quantitative and qualitative methods were used in analyzing the information collected using different instruments. Qualitative data obtained using semi-structured questionnaire; interview, observations, focal group discussion and document analysis were analyzed qualitatively using appropriate words. For quantitative data, descriptive statistics such as percentages and frequency were employed to analyze the gathered data.

\section{Farmers Awareness on Implementation Watershed Management Practice}

Table 1: Farmers Awareness and of watershed management practice implemented in the study area.

\begin{tabular}{|c|c|c|c|c|}
\hline Watershed management practice & Awareness of respondents about WSM practice & $\begin{array}{c}\text { Respondents implement WSM practice on their } \\
\text { farm land }\end{array}$ \\
\hline & Frequency (Awarded) & Percent & $\begin{array}{c}\text { Frequency } \\
\text { (Implemented) }\end{array}$ & Percent (\%) \\
\hline Organic manure/compost & 240 & 100 & 202 & 84.2 \\
\hline Soil bund & 226 & 94.2 & 226 & 84.2 \\
\hline Stone bund & 219 & 91.3 & 212 & 16.6 \\
\hline Trench & 24 & 10 & 40 & 15 \\
\hline Eye brow basin & 8 & 6 & 36 & 16 \\
\hline Micro basin & 16 & 6.7 & 28 & 11.7 \\
\hline Semicircular bund & 28 & 11.7 & 25 & 27.03 \\
\hline Check dam & 12 & 5 & 65 & 22.5 \\
\hline Crop rotation & 204 & 85 & 54 & 19.5 \\
\hline Making water ways & 84 & 35 & 47 & 100 \\
\hline Mulching & 116 & 48.3 & 204 & 68.3 \\
\hline Tree planting & 204 & 100 & 164 & 1.7 \\
\hline Contour plowing & 164 & 68.3 & 4 & \\
\hline Fallowing & 4 & 1.7 & & \\
\hline
\end{tabular}

The results presented in Table 1 below indicated that, there are various watershed management practice implemented in the study area to maintaining the livelihood for climate change adaptation. Among these, physical soil and water conservation

measures such as soil bunds, stone bunds; trench, eye brow basin, micro basins, check dam, contour plowing and water ways were widely practiced. The remaining conservation practices implemented in the study area were biological soil and water 
conservation structures such as organic manure/compost, crop rotation, intercropping, mulching, fallowing and tree planting. The district is characterized by undulating and steep topographic features which are not suitable for crop production. However, due to population pressure farmers were forced to cultivate these steeply slopes by supplementing soil and water conservation structures.

In order to know their awareness level regarding these watershed management practices, the investigators enquired the respondents by using open and close questioners. Accordingly, $94.2 \%, 91.3 \%$ and $68.3 \%$ of the respondents were confirmed that they have good attentiveness about soil bunds, stone bunds and contour plowing respectively. Besides, $10 \%$, $6 \%, 6.7 \%, 11.7,5 \%$ and $35 \%$ of the respondents also replied that they have good awareness about trench, eye brow basin, micro basin, check dam, and water ways construction respectively. Concerning biological soil and water conservation structures, all respondents (100\%) have awareness about organic manure/ compost and tree planting. Additionally, 85\%, 90.8, 48.3, 1.7\%, of them have good awareness about crop rotation, intercropping, mulching and fallowing consecutively. Furthermore, 84.2\%, $94.2 \%, 22.5$ and $68.3 \%$ of the respondents were implement soil bund, stone bund, water ways and contour plowing on their farm land respectively (Table 1 ).

Additionally, $27.03 \%, 90.8 \%, 19.58 \%, 1.7 \%$, of them were implemented crop rotation, intercropping, mulching and fallowing on their farm land consecutively. As compared to their level awareness, the most awarded farmers were implemented these conservation measures on their own farm land. This indicated that the more they aware, the better they implement watershed management practice on their farm land. In line with this, [10] suggests that an increase in knowledge/awareness, attitudes and skills of soil conservation increase farmers' participation in the implementation of conservation watershed management. [11] also found a significant and positive correlation between farmers' awareness and participation in implementation of watershed management operations.

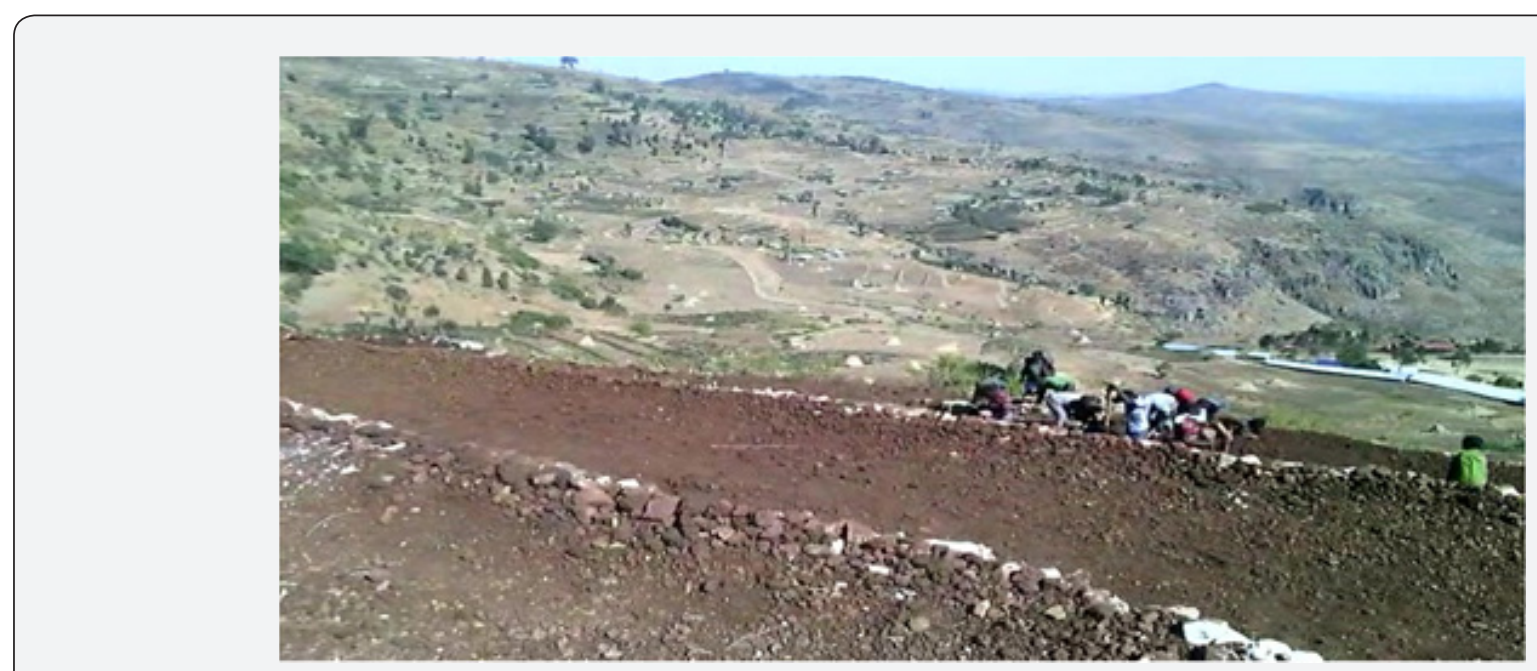

Figure 2: Stocking sorghum stalk for fuel wood and fodder.

Even though the study area is categorized under moisture stressed, the attention given for implementation of in-situ moisture conservation structures such as micro basin, eye brow basin, trenches and semicircular bunds were very low. The result presented in Table 1 also indicated, that only 16.6\%, 15\%, 6.7\% and $11.7 \%$ of the respondents were implemented trenches, eye brow basins, micro basins and semicircular bunds in-situ moisture conservation structures on their farm lands. Moreover, low attentions were also given for implementation of mulching and fallowing practices in the study area. Due to shortage of farm and grazing land of farmers were forced to cultivate their farm land without fallowing and also mulching. The field observation and FGD discussion result indicated that

complete removal of sorghum and maize stalk from farm land for fodder and fuel wood is common practice in this area (Figure 2). The study conducted by [12] also approved that maize and sorghum stalks in Hararghe zones are commonly used as an energy source. However, covering of the soil with residues such as straw, maize/sorghum stalks or standing stubble is effective in reducing runoff and erosion since it protects the ground from the impact of raindrop, slows down the movement of flow water over the surface, and improves the infiltration rate, as the pores of the soil are not clogged. The removal of such crop residues from the fields, without replacement of nutrients tends to deplete the soil of nutrients. In large parts of Oromiya highlands fuel wood deficits were and still are mainly made up by substituting dung, grass, and straw.

\section{Factors Initiated Them to Implement Conservation Practices}

There are various factors initiated the respondents to apply these watershed management practices on their farm land. Among these factors susceptibility of the farm lands to erosion, soil fertility decline and scarcity of rain are common. Accordingly, $40 \%$ of the respondents were initiated to apply 
these SWC structures due to susceptibility of their farm land to erosion, presence of soil fertility decline and scarcity of rain fall. Besides, $35 \%$ of them were stated both soil fertility decline and scarcity of rain fall as a main reason. The remaining $10 \%$ and
$15 \%$ were listed susceptibility of their farm land to erosion and Soil fertility decline as their motivation to apply these watershed management practices respectively (Figure 3).

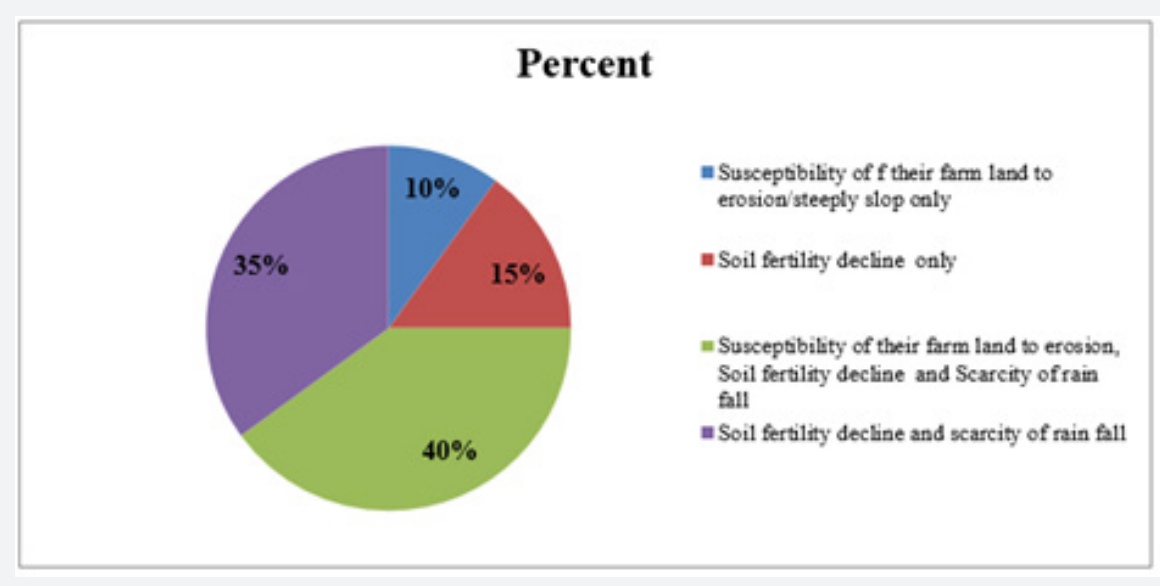

Figure 3: Factors initiated respondents to implement SWC practices.

\section{Impact Watershed Management on Common Livelihood Resources}

Table 2: Change observed on common livelihood resources after implementation of watershed management practice.

\begin{tabular}{|c|c|c|c|c|c|}
\hline \multirow{2}{*}{ No } & \multirow{2}{*}{ Change happen } & \multicolumn{2}{|c|}{ Frequency } & \multicolumn{2}{|c|}{ Percent } \\
\hline & & Yes & No & Yes & No \\
\hline 1 & Change in vegetation cover/land rehabilitation & 228 & 12 & 95 & 5 \\
\hline 2 & Reduce runoff impact/Soil erosion & 232 & 8 & 96.7 & 3.3 \\
\hline 4 & Moisture retention & 236 & 4 & 98 & 2 \\
\hline 5 & Change in ground water table from wells dug by villagers & 223 & 17 & 93 & 7 \\
\hline 6 & Improved soil fertility & 232 & 8 & 96.7 & 3.3 \\
\hline 7 & Change in capacity of spring/number & 189 & 51 & 78.8 & 21.2 \\
\hline 8 & Creation of village investment funds from the sale of produce from the commons (fodder) & 180 & 60 & 75 & 25 \\
\hline 9 & Conflict over natural resource decrease & 240 & 0 & 100 & 0 \\
\hline 10 & Social relationship between community improved & 240 & 0 & 100 & 0 \\
\hline 11 & Habits of working in groups improved & 240 & 0 & 100 & 0 \\
\hline 12 & Knowledge about natural resource utilization increased & 240 & 0 & 100 & 0 \\
\hline 13 & Giving value/ price for all-natural resource improved & 228 & 12 & 95 & 5 \\
\hline 14 & Increase in cropping intensity and yields of both irrigated and dry land crops & 180 & 60 & 75 & 25 \\
\hline 15 & Reduction in the threat of drought to crop and livestock production & 200 & 40 & 83.3 & 16.7 \\
\hline
\end{tabular}

Change in Vegetation Coverage: According to woreda NR sector report and FGD a vast hectare of degraded and deforested land was covered by tree plantation within five years and others were revegetated after demarcation and protected from human and animal encroachment. Furthermore, $95 \%$ of the respondent were confirmed that vegetation coverage has been improved since they stared to participated on community mobilization for watershed management activates (Table 2). For better estimation of change by the respondents, the investigators were categorized the levels of changes in vegetation coverage into three classes as localized (if the change was $\leq 25 \%$ ), Moderate (for $25 \%-50 \%$ change) good (if $\geq$ to $50 \%$ change were observed). Accordingly, $59.2 \%$ of the respondents were estimated the change in vegetation cover as moderate. The remaining $33.3 \%$ and $7.5 \%$ were estimated the change as good and localized respectively (Table 2). The FGD and key informants were also stated that due to integration of in-situ moisture conservation structures (eye brow basin, micro-basin, trenches etc) with tree plantation, the survival rates of the planted trees, forages seedlings and grasses growth were improved in moisture stressed area. This result is in line with [13] findings which stated that watershed management intervention was improved regular trees planting than the non-intervention one.

Change in Soil Erosion: As stated earlier, most land scape of the study area were not commonly suitable for crop cultivation. However, farmers have still cultivating sloppy land 
by supplementing with mechanical soil and water conservation such as soil bund, stone bund and bench terrace due to shortage of farm land. As a result, their farm lands including village/ settlement were strongly affected by frequent flood and soil loss prior to watershed treatment by community mobilization. Thus, an increased vulnerability to drought and food insecurity in the study area was directly linked to the degraded conditions of the watershed and their effects on limiting its capacity to support local livelihoods.

Currently, due to watershed management interventions through community mobilization an area exhibited multiple positive effects on people's livelihoods resources and environment. In line with this, $96.7 \%$ of the respondents were stated that soil erosion was reduced moderately (25-50\%) after the intervention/watershed treatment. Beside $27.1 \%$ of the respondents estimated the change as good ( $\geq$ to $50 \%$ ) (Table 2 \& 3) Thus any increase in productivity through better soil health and fertility will serve to moderate the impact of climate change on agricultural productivity (FAO, 2014). This result is also parallel with [14] which stated that soil erosion was reduced by more than $50 \%$ in treated watershed in India.

Impact of Watershed Management on Moisture Retention, Ground Water Recharge and Capacity of Spring: Increased in ground water table, soil moisture and spring capacity in watershed areas are an important measurable indicator of successful watershed intervention programme. Table 3: level of change as observed after implementation of watershed management practices.

\begin{tabular}{|c|c|c|c|c|}
\hline \multirow{2}{*}{ No } & \multirow{2}{*}{ Change happen } & \multicolumn{3}{|c|}{ Estimated of change in percentage } \\
\hline & & Localized $(\leq 25 \%)$ & Moderate (25\%-50\%) & Good ( $\geq$ to $50 \%$ ) \\
\hline 1 & Change in vegetation cover/ land rehabilitation & 7.5 & 59.2 & 33.3 \\
\hline 2 & Reduce runoff impact & 0 & 72.9 & 27.1 \\
\hline 4 & Moisture retention & 7.1 & 75.4 & 17.5 \\
\hline 5 & Change in ground water table from wells dug by villagers & 29.2 & 52.5 & 18.3 \\
\hline 6 & Improved soil fertility & 12.5 & 66.7 & 20.8 \\
\hline 7 & Change in capacity of spring/number & 12.5 & 64.2 & 23.3 \\
\hline 8 & $\begin{array}{l}\text { Creation of village investment funds from the sale of produce from } \\
\text { the commons (fodder) and creation of a revolving fund for small } \\
\text { loans at nominal interest. }\end{array}$ & 35 & 55.8 & 9.2 \\
\hline 9 & Conflict over natural resource decrease & 36.7 & 47.5 & 15.8 \\
\hline 10 & Social relationship between community improved & 12.5 & 54.2 & 33.3 \\
\hline 11 & Habits of working in groups improved & 12.2 & 54.2 & 33.3 \\
\hline 12 & Income diversification & 60 & 31.7 & 8.3 \\
\hline 13 & Knowledge about natural resource utilization increased & 10.8 & 65 & 24.2 \\
\hline 14 & Giving value/ price for all-natural resource improved & 9.2 & 55 & 35.8 \\
\hline 15 & $\begin{array}{l}\text { Increase in cropping intensity and yields of both irrigated and dry } \\
\text { land crops }\end{array}$ & 20.8 & 55 & 24.2 \\
\hline 16 & $\begin{array}{c}\text { Reduction in the threat of drought to crop and livestock } \\
\text { production }\end{array}$ & 44.2 & 42.5 & 13.3 \\
\hline
\end{tabular}

According to the respondents of FGD the practices of water conservation through different water harvesting structures had increased the potentiality of ground water level. The bund construction across their agricultural land stored the
Among various factors responsible for ground water recharge; soil bunds, stone bunds, hillside terraces and other in-situ water retention structures (eyebrow basin, micro basin and trenches) were widely implemented in the study area (Table 1). Increased in surface water or stream flow is another indicator that can help establishing positive impact of watershed development programmes on physical factors. Better infiltration will be contributing to the recharge of local groundwater, showed by a subsequent increase in the number of springs and much longer periods of base flow in the local watercourses, offering new opportunities for irrigation for the farming communities in the lower part of the watershed to increase resilience to climaterelated shocks.

In view of these, $98 \%, 93 \%$ and $96.7 \%$ of the respondents were stated that they were observed change in soil moisture retention, ground water table from wells dug by villagers and capacity of spring after implementation watershed development interventions respectively (Table 2). Based on their understanding $64.2 \%, 52.5 \%$ and $75.4 \%$ the respondents were estimated the change in moisture retention, ground water table and capacity of spring respectively as moderate (25-50\%) (Table 3 ). This improvements in soil moisture storage, the reduction of the erosive capacity of runoff and all options that help storing water, either in ponds, small reservoirs or in the ground were encouraged the adaptability of the farmers to climate change and variability. water in the agricultural field that helped in developing soil moisture and augmentation of groundwater. Thus, watershed management intervention can increase the adaptive capacity of beneficiary farmers to cope with the alarming threat of climate 
change and variability and improving livelihoods [4]. This result was confirmed with the study conducted by [15]. Other study conducted by [13] in Kaffa Zone also concluded that, the availability of water in the intervention area is better than the nonintervention one.

Impact of Watershed Management on Soil Fertility and Crop Yield: Hararghe Zones including the study area are well known by watershed treatments specially farm land terracing. These terraces contributed a significant role by reducing soil erosion, deforestation and improving moisture retention. The past study in east Hararghe zone indicated that watershed treatment by physical soil and water conservation structure was reduced soil erosion problem in sloppy farm lands and yields some desirable effect on some soil physicochemical properties which in turn improved the productive capacity of the land [16]. This survey results also confirmed that, $96.7 \%$ and $75 \%$ of the respondents were observed improvement in soil fertility and crop yield respectively, on their farm land after watershed treatment by land terracing (Table 2).

Additionally, the respondents estimate these changes in percentage based on their understanding. According, 66.7\% of the respondents were estimated the change as moderate (25-50\%) while $20.8 \%$ and $12.5 \%$ of them were estimated as good $(\geq 50 \%)$ and localized $(\leq 25 \%)$ respectively (Table 3 ). The respondents and also key informants related this change with increased in residual moisture content, decreased in soil erosion and hence protection of fertile top soil and Increased of ground water for supplemental irrigation due to contour bunding (level bunds), helping in crop growth and yield. These indicated that watershed management interventions in the study area provided significant change by reducing runoff and soil erosion, improving basin hydrology, maintaining and/or improving farmland soil fertility and thereby improving/maintaining agricultural production, reducing sediment load to natural and human-made reservoirs and reducing further degradation.

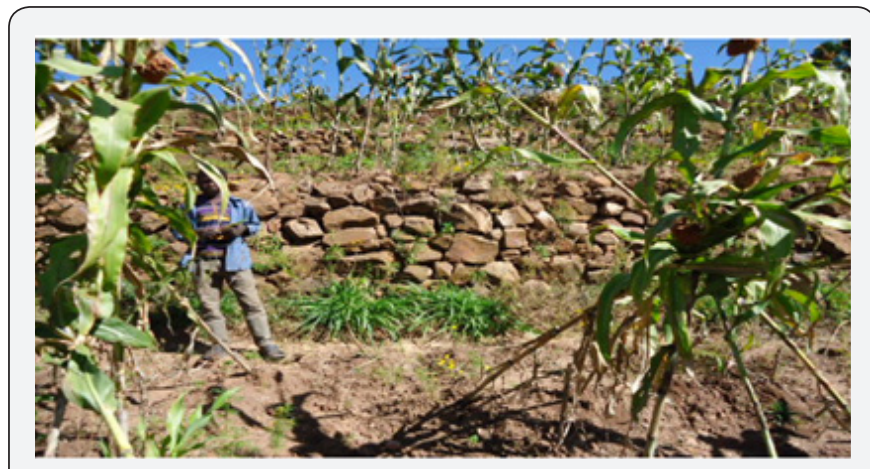

Figure 4: Stone bund implimented on farm land.

Similar to this result [15] also observed 200-300\% increase in crop productivity in Tigry region as the result of implementation of watershed management [17] also found that watershed interventions increased significantly the additional net returns from crop production as compared with the pre-watershed intervention period. Integrated watershed management approach enabled farmers to diversify the system along with increasing agriculture productivity through increased water availability, while conserving the natural resource base. Furthermore, [14] found an increase in productivity of all major crops after watershed management intervention in India. Household incomes increased substantially, leading to improved living and building the resilience of the community and natural resources [18] also indicated the watershed program significantly improved the socio-economic status of the watershed community (Figure 4).

Furthermore, $60 \%$ of the respondents also specified that due to implementation of watershed management practices, village investment funds from the sale of produce specially forage were improved. Among these respondents 35\%, 55.5\% and 9.2\% were ranked the improvement as localized $(\leq 25 \%)$, moderate (25\%-50\%) and good ( $\geq$ to $50 \%$ ) respectively. All of respondents $(100 \%)$ stated that their knowledge about natural resource utilization, social relationship and habits of working in groups were improved after participation on community mobilization for watershed management activities. The summarized result of FGD and key informants also indicated that the conflicts among communities over natural resource were also reduced. Prior to watershed management implementation there were strong conflicts between upstream and downstream users for land, forest and water because of the limited access of poor people to these resources. Currently, due to hydrological interlinked of upstream and downstream pressure on these resources were reduced. Furthermore, $83.3 \%$ of the respondents were also stated that due to better understanding of climate change coping mechanisms their threat of drought to crop and livestock production were reduced comparatively.

\section{Conclusion and Recommendation}

\section{Conclusion}

This paper studied the awareness and implementation of watershed management practices including the level of community participation in Gemechis district, West Hararghe Zone, Oromiya Regional State. The survey was also examined the impact of watershed management interventions on livelihood for climate change adaptation. According to this survey results, more than half ie. $94.2 \%, 91.3 \%$ and $68.3 \%$ of the respondents were equipped good awareness about soil bunds, stone bunds and contour plowing, respectively. Additionally, 85\%, 90.8\%, $48.3 \%$ and $100 \%$ of them were familiarized with crop rotation, intercropping, mulching and organic manure/compost, consecutively. Furthermore, $84.2 \%, 94.2 \%, 68.3 \%$, and $90.8 \%$, of the respondents were implement soil bund, stone bund, water ways and contour plowing on their farm land respectively.

Even though the study area is categorized under moisture stressed, the attention given for implementation of in-situ moisture conservation structures were very low. As evidence, only $16.6 \%, 15 \%, 6.7 \%$ and $11.7 \%$ of the respondents were implemented trenches, eye brow basins and micro basins, 
respectively. Additionally, due to shortage of farm land fallowing and crop rotation were not practiced extensively. Complete removal of sorghum and maize stalk from the farm land for fodder and fuel wood were also identified as common practice which expedited soil erosion and nutrient losses in the study area.

As a result of watershed management interventions through community mobilization multiple positive effects were exhibited on people's livelihoods resources and environment. In line with this, $96.7 \%$ of the respondents were stated that soil erosion was reduced moderately (25-50\%), 98\%, 93\% and $96.7 \%$ of the respondents were quantified the in change in soil moisture retention, ground water table, respectively. Additionally, 96.7 $\%$ and $75 \%$ of the respondents were observed improvement in soil fertility and crop yield, correspondingly. These indicated that watershed management interventions in the study area provided significant change by reducing runoff and soil erosion, maintaining and/or improving farmland soil fertility and thereby improving/maintaining agricultural production, reducing sediment load to natural and human-made reservoirs and reducing further degradation.

\section{Recommendation}

Even though the study area is characterized by low rain fall, the implementation in-situ moisture conservation structure is still very low. Thus, more attention should be given for extension of such practices.

a. Complete removal of crop residue/stalk for fuel wood without protecting the soil from rain drop impacts and nutrient replacement should get the right consideration.

b. Further research should be conducted to explore the on socio economic impact watershed management for climatic change adaptation.

\section{References}

1. NAPA (National Adaptation Plan for Action) (2007) Climate Change NAPA of Ethiopia. Addis Ababa: MoWER and NMA, Ethiopia.

2. Malo M, Jember G, Woodfine AC (2012) Strengthening Capacity for Climate Change Adaptation in the Agriculture Sector in Ethiopia, Proceedings from National Workshop held in Nazreth, Ethiopia.

3. UNEP (United Nation Enivronmental Program) (2002) African Enivronmental Outlook. Past, Present and Future Perspectives.

4. Food and Agriculture Organization of The United Nations (FAO) (2014) Adapting to climate change through land and water management: in Eastern Africa Results of pilot projects in Ethiopia, Kenya and Tanzania, Rome.
5. Darghouth S (2008) Watershed Management Approaches, Policies, and Operations: Lessons for Scaling Up. WB Water Sector Board Discussion Paper 11: 37-40.

6. IPCC (2007) IPCC Fourth Assessment Report: Climate Change 2007 (AR4), IPCC, Geneva, Switzerland.

7. G Debalkie, B Solomon (2014) Community-based, participatory integrated watershed management as an approach to climate change adaptation in Haro Jila and Wurba watersheds. Ethiopia.

8. DOA (district office of agriculture) (2012) Report of gemechis district office of agriculture. International Food Policy Research Institute (IFPRI) 2009. Climate Change.

9. GirmaTeshome, Belay Kassa, BezabihEmana, Jema Haji (2013) Patterns and Determinates of Farm Households' Investment in Rural Ethiopia: The Case of East Hararghe Zone, Oromia National Regional State. American Journal of Economics 3(4): 191-198.

10. Nuraeni Aminah Muchdar (2013) The influence of internal and external factors on farmers perception and participation in Jeneberang Watershed 77conservation. World Applied Sciences Journal 22(11): 1639-1643.

11. Mohammadi Golrang B, Lai FS, Rostami M, Kamurdin MN, Kamziah AK, et al. (2012) The Relationship Between Knowledgeof Watershed Management Operation and Level of People Participation. NY Sci J 5(12): 227-233.

12. Bezuayehu Tefera, Gezahegn Ayele, Yigezu Atnafe, Jabbar MA, Paulos Dubale (2002) Nature \&causes of land degradation in the Oromiya Region: A review. Socio-economic \&Policy Research Working Paper 36. ILRI (International Livestock Research Institute) Nairobi Kenya, pp. 82.

13. Meshesha YB, Birhanu BS (2015) Assessment of the Effectiveness of Watershed Management Intervention in Chena Woreda, Kaffa Zone, Southwestern Ethiopia. Journal of Water Resource and Protection 7: 1257-1269.

14. Prem, Hari, Aradhana (2010) Impact and effectiveness of watershed development programmes in India (Review and analysis of based on the studies Conducted by Various Government Agencies and Other Organisations) p. 55.

15. Gebregziabher G, Abera DA, Gebresamuel G, Giordano M, Langan $S$ (2016) An assessment of integrated watershed management in Ethiopia. Colombo, Sri Lanka: International Water Management Institute (IWMI) pp. 28.

16. Dejene Teressa (2017) The Effectiveness of Stone Bund to Maintain Soil Physical and Chemical Properties: The Case of Weday Watershed, East Hararge Zone, Oromia, Ethiopia. Civil and Environmental Research $9(12)$.

17. Wani SP, Garg KK, Singh AK, Rockstrom J (2012) Sustainable management of scarce water resource in tropical rainfed agriculture. In Soil Water and Agronomic Productivity, ed R Lal and BA Stewart, 347-408. Advances in Soil Science. CRC Press: United Kingdom, USA.

18. Chourasia PP, Wani AK, Raghavendra, Sudi SP (2013) Multiple impact of integrated watershed management in low rainfall semi arid region: a case study from Eastern Rajasthan, India. Journal of Water Resource and Protection 5(1): 27-36. 
This work is licensed under Creative Commons Attribution 4.0 License

DOI: 10.19080/IJESNR.2018.15.555906
Your next submission with Juniper Publishers will reach you the below assets

- Quality Editorial service

- Swift Peer Review

- Reprints availability

- E-prints Service

- Manuscript Podcast for convenient understanding

- Global attainment for your research

- Manuscript accessibility in different formats ( Pdf, E-pub, Full Text, Audio)

- Unceasing customer service

Track the below URL for one-step submission https://juniperpublishers.com/online-submission.php 